\title{
Effect of Environmental Factors on Growth Performance of Murrah Buffalo Heifers
}

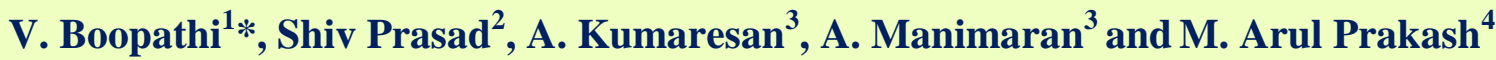 \\ ${ }^{1}$ Department of Livestock Production Management, Veterinary College and Research \\ Institute, Namakkal-637002, Tamil Nadu Veterinary and Animal Sciences University \\ (TANUVAS), Tamil Nadu \\ ${ }^{2}$ Indian Council of Agricultural Research (ICAR), Krishi Bhavan, New Delhi \\ ${ }^{3}$ ICAR-National Dairy Research Institute, Southern Regional Station, Bangalore, India \\ ${ }^{4}$ Department of Livestock Production Management, Veterinary College and Research \\ Institute, Orathandu, Tanjore, Tamil Nadu Veterinary and Animal Sciences University \\ (TANUVAS), Tamil Nadu
}

*Corresponding author

\begin{abstract}
A B S T R A C T
Live body weight data from 288 Murrah buffalo female calves maintained at the Livestock Research Center, Karnal, Haryana, India, born in the period between 2000 and 2009 were used for this study. Data were analysed using least-squares procedures. The overall mean for birth weight of Murrah buffalo female calves was $32.32 \pm 0.31 \mathrm{Kg}$. The mean body weight at $3^{\text {rd }}, 6^{\text {th }}, 9^{\text {th }}, 12^{\text {th }}, 15^{\text {th }}, 18^{\text {th }}, 24^{\text {th }}, 30^{\text {th }}$ and $36^{\text {th }}$ months of age pooled over season, periods and birth weight were $65.0 \pm 0.51,108.78 \pm 0.97,139.07 \pm 1.43$, $174.82 \pm 1.80,211.20 \pm 2.20,255.21 \pm 2.30,338.39 \pm 2.56,405.75 \pm 3.29$ and $470.50 \pm 3.87 \mathrm{~kg}$, respectively. The overall mean values of body weight at sexual maturity and weight at first calving of Murrah buffaloes were $413.60 \pm 3.68 \mathrm{Kg}$ and $569.60 \pm 5.13 \mathrm{Kg}$. Period of calving influenced the weight significantly almost all month of ages in this study. The calves born during the summer season were generally heavier and gained more body weight than those born in other seasons. Birth weight of calves influenced the body weight significantly at $3^{\text {rd }}, 18^{\text {th }}$ months of age only and also influences the weight at sexual maturity and weight at first calving. The phenotypic parameter estimates indicated that the more than $6^{\text {th }}$ month of body weights can be used as a selection tool for improvement of growth traits considering its highly positive phenotypic correlations with succeeding growth traits.
\end{abstract}

\section{Introduction}

The present buffalo's population in India is 108.70 million, which is first position in the world. Buffalo, the premier dairy animal in India contributing approximately $56 \%$ of total milk produced in the country (CIRB Annual report, 2004-15). Murrah is an important milk breed of buffalo and genetic improvement of growth of Murrah buffaloes is of great importance in the large ruminant industry in India. Growth rate is an important trait that 
determines the age at which an animal will reach puberty and conceive and directly influences the age at first calving which ultimately determines the lifetime productivity of an animal (Lawrence and Fowler, 1997). It is expected that animals growing faster in terms of body weight may also initiate physiological functioning of reproduction and milk production earlier. Reports on growth performance of Murrah buffaloes were few (Basu and Rao, 1979; Patnaik, 1988; Yadav et al., 2001; Kumaravel et al., 2004) and little is known about the environmental factors that can interfere with body weight at different ages in Murrah buffaloes. The present study aimed to evaluate influence of environmental factors on body weight at different ages of Murrah buffaloes. The above study will help to formulate suitable evaluation procedures especially in organised farms for improving economic traits of this breed.

\section{Materials and Methods}

The records of 288 female Murrah calves born at Livestock Research Center, National Dairy Research Institute, karnal (Haryana) during 2000-2009 were collected and utilized for this study. Animals were reared under intensive housing system of management. Regular weighing was done at birth to every months of age. The data were analysed to examine the effects of period, season and birth weight on body weight at different ages. The entire periods was grouped into three periods comprising first period (P1) from 2000-2003, second period (P2) from 20042006 and third period (P3) from 2007-2009. Each year divided into four seasons viz. winter (December to march), summer (April to June), rainy (July to august) and autumn (September to November). The birth weight was classified into $\mathrm{G} 1$ (less than $25 \mathrm{Kg}$ ), G2 (25-30 Kg), G3 (31-35 Kg) and G4 (more than $35 \mathrm{Kg}$ ). The data were subjected to leastsquares analysis of variance using LSMLMW
PC-2 VERSION software package (Harvey, 1990). The means in different treatments were tested for statistical significance using Duncan's multiple range tests. The Pearson's coefficient of correlation technique was used for analysis of phenotypic correlations. The data were analysed using a mixed model least-squares analysis for fitting constants, including all main effects with interactions. All the experimental procedures were duly approved by Institute Animal Ethical Committee of National Dairy Research Institute (NDRI), Karnal.

The model was:

$Y_{i j k m}=\mu+P_{i}+S_{j}+B_{k}+e_{i j k m}$

Where,

$\mathrm{Y}_{\mathrm{ijkm}}=$ observed body weight at different ages,

$\mu=$ population mean,

$\mathrm{P}_{\mathrm{i}}=$ effect of $\mathrm{i}^{\text {th }}$ period $(\mathrm{i}=1$ to 3$)$,

$S_{j}=$ effect of $j^{\text {th }}$ season $(j=1$ to 4$)$,

$\mathrm{B}_{\mathrm{k}}=$ effect of $\mathrm{k}^{\text {th }}$ group of birth weight $\left({ }_{\mathrm{k}}=1\right.$ to 4 ),

$\mathrm{e}_{\mathrm{ijkm}}=$ random errors.

\section{Results and Discussion}

\section{Growth performance}

The overall least squares mean estimates $( \pm$ S.E) for birth weight of Murrah buffalo female calves was $32.32 \pm 0.31 \mathrm{Kg}$. This is very close to the values reported by (Basu and Rao, 1979) and (Thiruvenkadan et al., 2010) for Murrah female calves. The birth weight observed in the present study was higher than those reported by (Veerapandian et al., 1996); (Yadav et al., 2001) and (Kumaravel et al., 2004) on the same breed. However, the present estimate was lower than the value reported by (Neeta Sharma, 2012) for Murrah female calves. 
The least-squares mean estimates $( \pm$ S.E) of weight at $3^{\text {td }}, 6^{\text {th }}, 9^{\text {th }}, 12^{\text {th }}, 15^{\text {th }}, 18^{\text {th }}, 24^{\text {th }}, 30^{\text {th }}$ and $36^{\text {th }}$ months of age were $65.0 \pm 0.51$, $108.78 \pm 0.97,139.07 \pm 1.43,174.82 \pm 1.80$, $211.20 \pm 2.20, \quad 255.21 \pm 2.30, \quad 338.39 \pm 2.56$, $405.75 \pm 3.29$ and $470.50 \pm 3.87 \mathrm{~kg}$, respectively (Table 1 and 2) and the mean growth rate from birth to $12^{\text {th }}$ months ,birth to $24^{\text {th }}$ months and birth to $36^{\text {th }}$ months of age were $456.22 \pm 5.50,479.81 \pm 4.22$ and 409.31 $\pm 3.66 \mathrm{~g} /$ day respectively. The body weight observed at different ages were comparable to the values already reported by (Basu and Rao 1979) and (Patnaik 1988) on the same breed. The body weight up to $6^{\text {th }}$ months of ages reported by (Thiruvenkadan et al., 2009) and (Kumar et al., 2007) were also comparable to the present estimates, however they reported lower weights at $9^{\text {th }}, 12^{\text {th }}, 15^{\text {th }}, 18^{\text {th }}$ and $24^{\text {th }}$ months of age. The higher value observed in the present study compared to reports from south India might be due to genotype and environmental factors interaction. The climatic condition in southern coastal region is hot, semi-arid and humid in nature; whereas the climatic conditions of murrah buffalo in its breeding tract are generally hot, semi-arid and dry in nature. The climatic conditions of Haryana (breeding tract of murrah buffalo) are perhaps the reason for the higher body weight of Murrah breed in this region. However, this needs further detailed investigation.

\section{Body weight at sexual maturity and first calving}

The overall least squares mean estimates $( \pm$ S.E) for body weight at sexual maturity was $413.60 \pm 3.68 \mathrm{Kg}$ (Table 2). It is higher than those reported by (Saini et al., 1998) and (Basu et al., 1984) for Murrah buffalo. However, the present estimate was lower than the values reported by Rathi et al., (1971) for Murrah buffaloes. The overall least squares mean estimates $( \pm$ S.E) for body weight at first calving was $569.60 \pm 14.96 \mathrm{Kg}$ (Table 2). It is higher than reported values by (Saini et al., 1998) and (Basu et al., 1984) for murrah buffalo. However, the present estimate was lower than the values reported by (Rathi et al., 1973) for murrah buffaloes. The variation in the estimates of the present study and some other earlier studies may be due to differences in the size of data set, the state of nutrition and other managemental conditions. The animals maintained at high state of nutrition mature and conceive earlier than those raised at low state of nutrition (Shah 1991) The estimates of genetic correlation between birth weight and weight at different ages were medium to high and positive and it is in accordance with the previous reports on Murrah buffaloes (Salces et al., 2006).

\section{Influence of environmental factors on growth performance of Murrah buffalo heifers}

\section{Period of birth}

The period of birth had significant to highly significant $(\mathrm{P}<0.01)$ effect at all the ages of body weight (Table 1 and 2) under this study and this might be due to variation in management practices and availability of good quality fodder over the periods and difference in period involved in the study. It is in accordance with the report of (Yadav et al., 2001) and (Thiruvenkadan et al., 2009). But the same time period did not have any significant $(\mathrm{P}>0.05)$ effect on birth weight of Murrah buffaloe calves. On the contrary, Thiruvenkadan et al., (2010) and (Yadav et al., 2001) observed that the period of birth had significant to highly significant effect on birth weight. However, calves born during the period 2006-2009 had higher birth weight $(33.30 \pm 0.57 \mathrm{Kg})$ compared to those born during the period of 2000-2003 (31.74 \pm 0.47 $\mathrm{Kg}$ ).This might be due to variation in management practices and availability of quality fodder over the periods. 
The period of birth had no significant ( $P>0.05)$ effect on body weight at sexual maturity and body weight at first calving in Murrah heifers (Table 2). Present findings are in agreement with those of (Basu et al., 1984) and (Singh and Dhillon 1975), who also observed non significant effect of periods on body weight at sexual maturity and age at first calving in Murrah heifers. Higher body weight at sexual maturity $(419.14 \pm 6.11 \mathrm{Kg})$ was observed for the heifers were born during the period of 2006-2009, while the lower body weight at sexual maturity (406.97 \pm 5.10 $\mathrm{Kg}$ ) was observed for the heifers born during the period of 2000-2002. It could be due to improvement in the feeding management of the buffalo heifers over the years. Body weight at puberty such as ovarian cyclic activity were affected by different farm conditions especially by feeding levels that improved growth and sexual maturity Borghese et al., (1994).

\section{Season of birth}

The effects of season of had significant $(\mathrm{P}<0.05)$ on birth to $12^{\text {th }}$ month of ages under study (Table 1 and 2). Seasonal changes in the availability of fodder may affect the body weight by altering growth rate after rumen development of calves. However, calves born during summer season had the higher $(32.57 \pm 0.59 \mathrm{Kg})$ birth weight compared to those born during rainy season $(31.01 \pm 0.75$ $\mathrm{Kg}$ ). The calves born during summer season subsequently weaned by in winter season got good nutrition leads to more body weight upto $12^{\text {th }}$ months of age. The findings of present study regarding heavier weights of the calves born during summer season than calves born during other seasons were in agreement with the findings of (Basu and Rao, 1979) and (Kumaravel et al., 2004). However, on the contrary season of birth had no significant on body weight at different ages reported by (Yadav et al., 2001) and (Thiruvenkadan et al. 2009).
The effect of season of birth was found to be non significant $(\mathrm{P}>0.05)$ on body weight at sexual maturity and body weight at first calving (Table 2). Present findings are in agreement with those of (Basu et al., 1984) and (Singh and Dhillon 1975), who observed no significant effect of season of birth on body weight at sexual maturity and body weight at first calving in Murrah buffaloes.

\section{Birth weight}

The birth weight had highly significant $(\mathrm{P}<0.01)$ effect on $3^{\text {rd }}$ and $18^{\text {th }}$ months of body weight only in Murrah calves (Table 1 and 2). The calves born with birth weight more than $35 \mathrm{Kg}$ had maximum $(70.66 \pm 0.87$ $\mathrm{Kg}$ ) body weight at three month of age. While, calves born with birth weight less than $25 \mathrm{Kg}$ had minimum $(58.69 \pm 1.48 \mathrm{Kg})$ body weight at three month of age. Results showed that the calves heavier at birth were also heavier at three months of age. It might be the higher birth weight influencing only three month age after that only based on management and environment and also calves well adapted to the new environment.

The effect of birth weight on body weight at sexual maturity and weight at first calving was statistically found to be significant $(\mathrm{P}<0.01)$ in Murrah buffaloes (Table 1 and 2). There is no report available on the effect of birth weight on age at first calving in murrah buffaloes. On the other hand, Wakchaure and Meena (2010) observed a non-significant effect of birth weight on the weight at first calving and (Dhangar and Patel, 1992) also observed non-significant effect of birth weight on weight at first calving (AFC) in crossbred heifers. The calves born with birth weight more than $35 \mathrm{Kg}$ had highest $(596.48 \pm 8.77 \mathrm{Kg})$ weight at first calving. Calves born with birth weight less than $25 \mathrm{Kg}$ had the lowest body weight at first calving $(544.94 \pm 8.77 \mathrm{Kg})$. 
Table.1 Least square M.E \pm S.E for body weight $(\mathrm{Kg})$ of Murrah buffaloes

\begin{tabular}{|c|c|c|c|c|c|c|}
\hline$n=288$ & $3^{\text {rd }}$ months & $6^{\text {th }}$ months & $9^{\text {th }}$ months & $12^{\text {th }}$ months & $15^{\text {th }}$ months & $18^{\text {th }}$ months \\
\hline Seasons & \multicolumn{6}{|c|}{$* *$} \\
\hline Winter (69) & $62.59 \pm 0.88^{\mathrm{a}}$ & $106.80 \pm 1.68$ & $133.66 \pm 2.48^{\mathrm{a}}$ & $165.55 \pm 3.13^{\mathrm{a}}$ & $213.55 \pm 3.68^{\mathrm{a}}$ & $257.79 \pm 3.99$ \\
\hline Summer (44) & $66.33 \pm 1.09^{b}$ & $109.95 \pm 2.02$ & $136.89 \pm 3.08^{b}$ & $182.33 \pm 3.88^{b}$ & $211.44 \pm 4.56^{\mathrm{a}}$ & $258.24 \pm 4.95$ \\
\hline Rainy (77) & $66.21 \pm 0.80^{b}$ & $108.42 \pm 1.53$ & $146.13 \pm 2.26^{c}$ & $179.85 \pm 2.85^{\mathrm{c}}$ & $217.54 \pm 3.35^{b}$ & $252.37 \pm 3.64$ \\
\hline Autumn (98) & $65.24 \pm 0.76^{b}$ & $109.94 \pm 1.44$ & $139.59 \pm 2.13^{d}$ & $171.55 \pm 2.67^{d}$ & $203.71 \pm 3.16^{\mathrm{c}}$ & $252.42 \pm 3.43$ \\
\hline Period & \multicolumn{2}{|l|}{$*$} & $* *$ & \multicolumn{2}{|l|}{$* *$} & $* *$ \\
\hline P1 (93) & $63.72 \pm 0.71^{a}$ & $106.93 \pm 1.34$ & $133.66 \pm 2.48^{\mathrm{a}}$ & $165.55 \pm 3.13^{a}$ & $213.55 \pm 3.68^{a b}$ & $259.26 \pm 3.19^{\mathrm{a}}$ \\
\hline P2 (116) & $64.85 \pm 0.76^{a}$ & $108.66 \pm 1.46$ & $136.89 \pm 3.08^{\mathrm{a}}$ & $182.33 \pm 3.88^{b}$ & $211.44 \pm 4.56^{\mathrm{ab}}$ & $267.03 \pm 3.46^{b}$ \\
\hline P3 (79) & $66.70 \pm 0.84^{b}$ & $110.73 \pm 1.61$ & $146.13 \pm 2.26^{b}$ & $179.85 \pm 2.85^{b}$ & $217.54 \pm 3.35^{b}$ & $239.33 \pm 3.82^{c}$ \\
\hline Birth weight & \multicolumn{3}{|c|}{$* *$} & & & $*$ \\
\hline $1(22)$ & $58.69 \pm 1.48^{\mathrm{a}}$ & $105.45 \pm 2.83$ & $137.56 \pm 4.17$ & $175.62 \pm 5.25$ & $204.25 \pm 6.18$ & $247.73 \pm 6.71^{\mathrm{a}}$ \\
\hline $2(95)$ & $63.49 \pm 0.71^{b}$ & $107.66 \pm 1.35$ & $136.22 \pm 2.00$ & $172.84 \pm 2.52$ & $208.69 \pm 2.96$ & $250.44 \pm 3.22^{\mathrm{a}}$ \\
\hline $3(108)$ & $67.52 \pm 0.67^{c}$ & $110.55 \pm 1.28$ & $139.54 \pm 1.89$ & $173.58 \pm 2.37$ & $217.56 \pm 2.80$ & $263.03 \pm 3.04^{\mathrm{b}}$ \\
\hline $4(63)$ & $70.66 \pm 0.87^{d}$ & $111.46 \pm 1.65$ & $142.97 \pm 2.44$ & $177.22 \pm 3.08$ & $215.75 \pm 3.62$ & $259.62 \pm 3.93^{b}$ \\
\hline Overall mean & $65.09 \pm 0.51$ & $108.78 \pm 0.97$ & $139.07 \pm 1.43$ & $174.82 \pm 1.80$ & $211.20 \pm 2.12$ & $255.21 \pm 2.30$ \\
\hline
\end{tabular}

$* * \mathrm{P}<0.01, * \mathrm{P}<0.05$. (Means with different superscript within columns for each group differ significantly) 
Table.2 Least square M.E \pm S.E for body weight $(\mathrm{Kg})$ of Murrah buffaloes

\begin{tabular}{|c|c|c|c|c|c|}
\hline$n=288$ & $24^{\text {th }}$ months & $30^{\text {th }}$ months & $36^{\text {th }}$ months & $\begin{array}{c}\text { Weight at } \\
\text { sexual maturity }\end{array}$ & $\begin{array}{l}\text { Weight at } \\
\text { first calving }\end{array}$ \\
\hline \multicolumn{6}{|l|}{ Seasons } \\
\hline Winter (69) & $334.94 \pm 4.44$ & $409.32 \pm 5.71$ & $461.17 \pm 6.71$ & $415.02 \pm 6.38$ & $573.89 \pm 8.90$ \\
\hline Summer (44) & $339.68 \pm 5.51$ & $409.65 \pm 7.08$ & $469.88 \pm 8.32$ & $409.18 \pm 7.92$ & $565.61 \pm 11.04$ \\
\hline Rainy (77) & $342.06 \pm 4.04$ & $398.55 \pm 5.21$ & $479.80 \pm 6.12$ & $412.77 \pm 5.82$ & $574.61 \pm 8.12$ \\
\hline Autumn (98) & $336.87 \pm 3.81$ & $405.48 \pm 4.91$ & $471.14 \pm 5.77$ & $417.42 \pm 5.48$ & $564.26 \pm 7.65$ \\
\hline Period & \multicolumn{3}{|c|}{$* *$} & \multicolumn{2}{|l|}{$* *$} \\
\hline P1 (93) & $349.81 \pm 3.55^{\mathrm{a}}$ & $422.66 \pm 4.57^{\mathrm{a}}$ & $491.37 \pm 5.36^{a}$ & $406.97 \pm 5.10$ & $575.92 \pm 7.12$ \\
\hline P2 (116) & $352.60 \pm 3.84^{b}$ & $423.38 \pm 4.95^{\mathrm{a}}$ & $482.50 \pm 5.81^{\mathrm{a}}$ & $414.68 \pm 5.53$ & $567.90 \pm 7.71$ \\
\hline P3 (79) & $342.77 \pm 4.25^{\mathrm{a}}$ & $391.19 \pm 5.47^{b}$ & $467.62 \pm 6.42^{b}$ & $419.14 \pm 6.11$ & $564.26 \pm 8.52$ \\
\hline Birth weight & \multicolumn{5}{|c|}{$* *$} \\
\hline $1(22)$ & $330.54 \pm 7.45$ & $407.59 \pm 5.60$ & $462.91 \pm 7.28$ & $396.09 \pm 10.73^{\mathrm{a}}$ & $544.94 \pm 14.96^{\mathrm{a}}$ \\
\hline $2(95)$ & $333.86 \pm 3.56$ & $399.01 \pm 4.60$ & $465.10 \pm 5.41$ & $402.48 \pm 5.14^{\mathrm{a}}$ & $560.95 \pm 7.18^{\mathrm{a}}$ \\
\hline $3(108)$ & $343.81 \pm 3.37$ & $404.55 \pm 4.35$ & $472.46 \pm 5.11$ & $419.05 \pm 4.86^{b}$ & $576.00 \pm 6.77^{\mathrm{ba}}$ \\
\hline $4(63)$ & $345.37 \pm 4.37$ & $411.87 \pm 5.62$ & $481.52 \pm 6.61$ & $436.77 \pm 6.28^{c}$ & $596.48 \pm 8.77^{b}$ \\
\hline Overall mean & $338.39 \pm 2.56$ & $405.75 \pm 3.29$ & $470.50 \pm 3.87$ & $413.60 \pm 3.68$ & $569.60 \pm 5.13$ \\
\hline
\end{tabular}


The variation in the estimates of the present study may be due to differences in the size of data set, the state of nutrition and other management conditions.

The study concluded that the environmental factors such as season and period of birth might be considered when performing an evaluation of Murrah calves based on growth traits. Therefore, the effects of environmental variables must be taken into consideration in the dairy animal for selection and evaluation purpose. The phenotypic parameter estimates indicated that the more than $6^{\text {th }}$ month of body weights can be used as a selection tool for improvement of growth traits considering its highly positive phenotypic correlations with succeeding growth traits. A positive response should be expected in selection for increased birth weight would also result in genetic improvement in the subsequent ages.

\section{Acknowledgments}

We express our deep gratitude to the director, National Dairy Research Institute (NDRI) Karnal and Head, Dairy Cattle Breeding Division, NDRI, Karnal for providing necessary facilities.

\section{Funding}

We express our sincere thanks to Indian Council of Agricultural Research (ICAR), New Delhi for providing financial support to carrying out this research work.

\section{Disclosure statement}

All authors declare that they have no relationship with people or organizations that could prejudice or bias the content of this paper.

\section{References}

Basu SB and Rao MK. (1979). Growth pattern in Murrah buffalo calves.
Indian Veterinary Journal (56): 570574.

Basu SB, Tomar OS and Ghai AS (1984).Genetic studies on sexual maturity traits of buffalo heifers. Indian Journal of Animal Sciences (54): 14-8.

Borghese A, Terzano GM, Barile VL, Parmeggiani A. (1994) Season and feeding level effects on onset of puberty in buffalo heifers. Proc. IV World Buffalo Congress, Sao Paulo, Brazil, 27-30 June, pp. 525-527.

Central Institute for Research on Buffaloes (CIRB), (2014-2015) Annual Report, Hissar, Haryana, India.

Dhangar MB and Patel JM. (1992).Factors Affecting Birth-Weight In Inter-Se Mated Jersey X Kankrej Calves. Indian Veterinary Journal 69(12): 1095-1098.

Harvey WR. User's guide for LSMLMW and MIXMDL PC-2 version. (1990). Mixed model least-squares and maximum likelihood computer program. Columbus (Ohio, U.S.A.): Ohio State University.

Kumar R, Jain AK and Mehra ML. (2007). Effect of inbreeding on body weight at different ages in graded Murrah buffaloes. Indian Veterinary Journal (84): 1148-1150.

Kumaravel N, Sivakumar T, Nisha PR and Gopi, H. (2004). Studies on some factors affecting birth weight in buffalo calves. Cheiron (33): 51-53.

Lawrence TLJ and Fowler VR. Growth and puberty in breeding animals. (1997).In: Growth of Farm Animals. CAB International, Wallingford, UK, pp. 251.

Neeta S. (2012). Development of computer models for production and reproduction performances of Murrah buffaloes [M.V.Sc Thesis, NDRI]. Karnal (India): Deemed University. 
Patnaik AKC. (1988). Body Weight and its Effect on First Lactation Yield in Murrah. M.V.Sc. thesis submitted to Tamil Nadu Agricultural University, Coimbatore, India.

Rathi SS, Balaine DS and Kanaujia AS. (1973). Body weights and their relationship with economic traits in Indian buffaloes. Indian Journal of Animal Production, 4 (1): 1-8.

Saini MS, Dhanda OP, Singh N and Georgie GC. (1998). The effect of improved management on the reproductive performance of pubertal buffalo heifers during the summer. Indian Journal of Dairy Science 51(4): 250253.

Salces CB, Salces AJ, Seo KS and Bajenting GP. (2006). Genetic parameters estimation of growth traits of Murrah buffaloes raised under ranch production system. Proc. $8^{\text {th }}$ World Congress on Genetic Applied to Livestock Production, August 13-18, Belo Horizonte, Brazil.

Shah SK. (1991). Buffaloes of Pakistan. Islamabad (Pakistan): Pakistan Agriculture Research Council.
Singh G and Dhillon IS. (1975). Environmental and genetic factors affecting the age at first calving and the first lactation yield of buffaloes. Journal of Research Punjab Agricultural University, 12(3): 286290.

Thiruvenkadan AK, Panneerselvam S, Rajendran R and Murali N. (2010). Analysis on the productive and reproductive traits of Murrah buffalo cows maintained in the coastal region of India. Applied animal husbandry and rural development 3(1): 1-5.

Veerapandian C, Chandran NDJ, Jayaraja S, Kathaperumal V. (1996). Pattern of calving and birth weight in Murrah buffaloes in an organised farm. Indian Veterinary Journal 73: 450-451.

Wakchaure RS and Meena R. (2010).Factors Affecting, Birth Weight, Age and Weight at First Calving in Sahiwal Cattle. Indian Journal of Animal Research 44(3): 173-177.

Yadav BS, Yadav MC, Singh A andKhan FH. (2001). Murrah buffaloes-1. Birth weight. Buffalo Bulletin20: 29-31.

\section{How to cite this article:}

Boopathi, V., Shiv Prasad, A. Kumaresan, A. Manimaran and Arul Prakash, M. 2020. Effect of Environmental Factors on Growth Performance of Murrah Buffalo Heifers. Int.J.Curr.Microbiol.App.Sci. 9(07): 2676-2683. doi: https://doi.org/10.20546/ijcmas.2020.907.315 